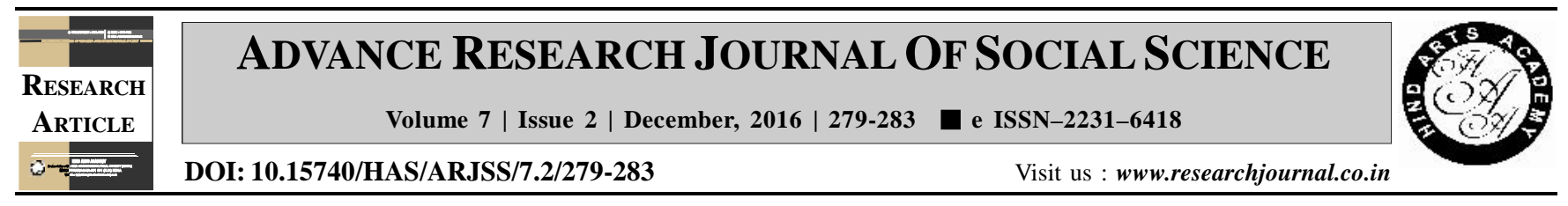

\title{
A comparative study on eating behaviour of public school and Government school children of Lucknow city
}

Atiqua Sultana* and Savita Ahluwalia ${ }^{1}$

Department of Home Science, University of Lucknow, LUCKNOW (U.P.) INDIA

${ }^{1}$ Department of Home Science, Mahila P.G. College, LUCKNOW (U.P.) INDIA

(Email: atiqua.1ko@gmail.com)

\begin{tabular}{lll}
\multicolumn{2}{l}{ ARTICLE INFO : } \\
Received & $:$ & 25.10 .2016 \\
Revised & $:$ & 15.11 .2016 \\
Accepted & $:$ & 28.11 .2016
\end{tabular}

KEY WORDS :

Public and government school girl's children, Eating behavior, Risk of diseases, Fast food

\section{HOW TO CITE THIS ARTICLE :}

Sultana, Atiqua and Ahluwalia, Savita (2016). A comparative study on eating behaviour of public school and Government school children of Lucknow city. Adv. Res. J. Soc. Sci., 7 (2) : 279283, DOI: 10.15740/HAS/ARJSS/7.2/ 279-283.

*Author for correspondence

\begin{abstract}
School health has been acknowledged as important since the beginning of $20^{\text {th }}$ century. Girls are the future mother and good nutrition is important component of healthy life. During school age years children begin to establish habits for eating and exercise that stick with them for their entire life. If children establish healthy habits, their risk for developing many chronic diseases will be greatly decreases. On the other hand poor eating habits and physical inactive children set the stage for health problems in adulthood. In today's life eating behaviour has change. Junk food has become a trend for school children. TV plays a major role. It gives information regarding the fast food products. Children attracted easily when children saw these advertisements it gives wrong impression on their minds and they start giving a lot of importance to materialistic joys. Junk food, such as pizzas, burgers and soft drinks are heavily promoted during children's TV viewing time. These develop a craving for fatty, sugary and fast food in children, there by affecting their heath adversely. The objective of the paper was to assess the eating behavior of public school and government school girls' children. 300 children was randomly selected from public and government school girl's children between the age or 10-12 years. Both school children were found highly influenced by the products shown of TV. Deficiency of the Good quality of protein was found in government school children. The higher intake of fats was found in public school children.71 per cent of extra fats in 10 years, 25.71 per cent in 11 years and 42.8 per cent in 12 years children was found extra in their diet.
\end{abstract}

